\title{
Insect Development and Evolution
}




\title{
Insect Development and Evolution
}

\author{
Bruce S. Heming \\ University of Alberta
}

COMSTOCK PUBLISHING ASSOCIATES a division of CORNELL UNIVERSITY PRESS Ithaca and London 


\section{Copyright $@ 2003$ by Cornell University}

All rights reserved. Except for brief quotations in a review, this book, or parts thereof, must not be reproduced in any form without permission in writing from the publisher. For information, address Cornell University Press, Sage House, 512 East State Street, Ithaca, New York 14850.

First published 2003 by Cornell University Press

Printed in the United States of America

Library of Congress Cataloging-in-Publication Data

Heming, B. S.

Insect development and evolution / Bruce S. Heming. p. $\mathrm{cm}$.

Includes bibliographical references (p. $)$.

ISBN 0-8014-3933-7 (cloth : alk. paper)

1. Insects-Development. 2. Insects-Evolution. 3.

Insects-Reproduction. I. Title.

QL495.5 .H46 2003

$571.8^{\prime} 157-\mathrm{dc} 21$

2002011087

Cornell University Press strives to use environmentally responsible suppliers and materials to the fullest extent possible in the publishing of its books. Such materials include vegetable-based, low-VOC inks and acid-free papers that are recycled, totally chlorine-free, or partly composed of nonwood fibers. For further information, visit our website at www.cornellpress.cornell.edu.

Cloth printing 10987654321 
To those students of insect structure and development whose elegant and ingenious contributions in the past contributed to our present spectacular success 
